\title{
WHAT AFFECTS IMPLEMENTATION OF GREEN BUILDINGS? AN EMPIRICAL STUDY IN HONG KONG
}

\author{
Vivian W. Y. TAM ${ }^{1}$, Jane L. HAO ${ }^{2}$ and S. X. ZENG ${ }^{3}$ \\ ${ }^{1}$ School of Computing, Engineering and Mathematics, University of Western Sydney, Locked \\ Bag 1797, Penrith South DC, NSW 1797, Australia \\ E-mail: vivianwytam@gmail.com; Tel: (61) 24736 0105; Fax: (61) 247360833 \\ ${ }^{2}$ Department of Architectural Science, Ryerson University, Canada \\ ${ }^{3}$ Aetna School of Management, Shanghai Jiaotong University, Shanghai, 200052, China
}

Received 7 August 2011; accepted 3 October 2011

\begin{abstract}
This paper examines the factors affecting the implementation of green buildings for the local construction industry. Questionnaire surveys and structural interviews were conducted to investigate the economical and social factors in the implementation of green buildings. From the survey results, the industry strongly believes that green building implementation is environment-friendly and can improve social values to the consumers. However, material costs, construction and transportation for green materials and green building features are more expensive than those for the conventional buildings. Four major factors affecting the existing limited implementation of green buildings were also discussed. Recommendations to improve the implementation of green buildings were also explored. This study can bring insights locally and around the world on how green buildings can be implemented to achieve environment-friendly, long-term cost saving and being recognized by the society and the consumers to reduce difficulties and burden encountered in the implementation.
\end{abstract}

KEYWORDS: Green buildings; Economics; Social; Hong Kong; Construction

\section{INTRODUCTION}

Environmental protection is an important issue around the world. Comparing with other industries, the building sector generates a large amount of pollutants, including noise, air, solid waste, and water (Morledge and Jackson, 2001; Ball, 2002). The impacts of buildings on the surrounding environment over their entire life cycle process have been recognized as serious problems for the construction industry (Polster et al., 1996).

The construction industry plays a vital role in meeting the needs of society and enhancing life quality. However, responsibilities for ensuring consistent construction activities and products with environmental policies need to be clearly defined, and effective environmental practices through waste reduction need to be promoted (Hong Kong Government - Environmental Protection Department, 2011). In Hong Kong and most of the other countries around the world, the building sector is one of the major contributors to environmental problems. Most of the resources consumed at construction sites are non-renewable, and some may even create adverse environmental impacts during their manufacturing processes (Griffith, 1995). Forty percent of waste reaching landfills was shown to be generated from the construction 
industry each year in Hong Kong (Hong Kong Government - Environmental Protection Department, 2011). The industry has been used to adopting non-environment-friendly practices such as the use of bamboo for scaffoldings, and non-inert materials for construction activities that would end up to landfills.

Materials from construction and demolition sites for recycling are mainly limited to concrete and reinforcement bars with the former being a contractual requirement or request from the government and the latter for their economic value (Tam et al., 2004). However, with the lack of financial incentives, recycling rates of the other low-valued construction debris are low. The main problems hindering waste recycling are (Kasai, 2004): (i) limited on-site space makes sorting and separation of construction and demolition waste difficult; (ii) demolition activities in urban areas are tightly scheduled to minimize nuisance to the consumers, opportunities for vandalism, and traffic congestion created around the site; (iii) knocking down structure as quickly as possible is the most efficient and the cheapest method of demolition in which only materials with market values are removed from the building; (iv) lack of recycling plants and facilities, especially for those generating hazardous substances during the process of recycling; (v) imbalanced supply and demand of recycled products making it difficult to find outlets for the recycled materials; (vi) quality requirements of recycled materials forming a hurdle in marketing recycled products; (vii) lack of standards for recycled products hindering their adoption; (viii) not wellestablished reuse and recycling technologies; and (ix) harmful materials released from the recycling processes.

The implementation of sustainable development has been set up by the Hong Kong government since 2003 (Hong Kong Government Environmental Protection Department, 2011). The Chief Executive of the Hong Kong Special Administrative Region, Ir. Donald Tsang, stated that to confront increasing demand of 'greener' environment, it is logical for 'green building' to be developed as a competitive constructional market in Asia. A green building is a structure that is designed, built, renovated, operated, or reused in an ecological and resource-efficient manner to incorporate energy efficiency, water conservation, waste minimization, pollution prevention, resource-efficient materials, and indoor environmental quality in all phases of its life (Wedding and CrawfordBrown, 2007; Yang and Hwang, 2007; Ding, 2008; Haapio and Viitaniemi, 2008; California Integrated Waste Management Board, 2011; Chang et al., 2011; Green Building Council Australia, 2011; The Seattle City Light Web Team, 2011). The appearance of a green building will be similar to any other buildings (Castro-Lacouture et al., 2009; Louisiana-Pacific Corporation, 2011). However, the difference is in the approach, which revolves round a concern for extending life spans of natural resources, and providing human comfort, safety and productivity (Burnett, 2007; Paul and Taylor, 2008; Indian Green Building Council, 2011; Kates, 2011).

Some of the salient features of a green building are (Burnett, 2007; Pan et al., 2008; Zhai and Wang, 2009; Chau et al., 2010; Issa et al., 2010): i) minimal disturbance to landscapes and site condition; ii) use of recycled and environment-friendly building materials; iii) use of energy efficient and eco-friendly equipment; iv) quality of indoor air quality for human safety and comfort; and v) effective control and building management systems.

There are a few construction-related environmental assessment tools in the market, such as the Building Research Establishment Environmental Assessment Method (BREEAM) (BRE, 2011), the Hong Kong Building Environmental Assessment Method (HKBEAM) (CET, 1999a; CET, 1999b; CET, 1999c) and the Leadership in Energy and Environmental Design (LEED) (USGBC, 2011). The BREEAM 
is a tool for surveyors and engineers to evaluate building life-cycle costs. Through the 'Ecolabelling' system, buildings are rated as excellent, very good, good and pass. The system mainly focuses on ecological and global effects of construction activities, such as carbon dioxide quantity emitted with less emphasis on issues like management and construction methods. The HKBEAM is a classification system in which buildings are divided into four categories according to their environment-friendliness: excellent, very good, good and fair whereas the LEED is a software tool used to measure environmental performance of a building site at an operational level; that is, technical information on site concerning daily environmental performance. A criticism of LEED is that it mainly concerns with technical aspect of environmental performance with much less emphasis on the management side.

Although there are many construction-related environmental assessment tools available in the market, there are limited studies in providing guidance on how to implement green building effectively. There are many researches working on how green building can help reduce energy consumption. Green buildings consume only $27 \%$ of energy compared with the conventional buildings as suggested by a China building Code (Pan et al., 2008). Using solar systems for green buildings, more than $70 \%$ of the total energy can be saved (Zhai et al., 2007). Approximately, it was also found that the performance of hybrid air-conditioning systems is $44.5 \%$ higher than conventional vapour compression systems at a latent load of $30 \%$, and this can be achieved by $73.8 \%$ at $42 \%$ latent load (Ma et al., 2006). However, there is no evidence to believe that green buildings are more comfortable, including aesthetics, serenity, lighting, ventilation, acoustics and humidity (Paul and Taylor, 2008). Indeed, the only difference between the green buildings and conventional buildings was that occupants of the green building were more likely to perceive their work environment as warm, and occupants who felt warm were more likely to describe their environment as poor (Paul and Taylor, 2008).

Cheng introduced a green building program and a water conservation index to quantitatively measure water conservation. The index involved standardized scientific quantification and can be used in a pre-design stage to obtain expected results (Cheng, 2003). A sustainable brownfield redevelopment tool had also been developed to quantify success in sustainability and green building development from brownfield revitalization (Wedding and CrawfordBrown, 2007). A multi-objective genetic algorithm was employed to find optimal solutions in assisting designers in green building design and evaluating design alternatives for both economical and environmental criteria (Wang et al., 2005). A neural network approach and a global sensitivity analysis have been developed to predict cost premium of LEED certified green building based on LEED categories and the possible relationships between input and output variables of the prediction model (Tatari and Kucukvar, 2011). A mixed integer optimisation model has also been developed to select the right materials and incorporate design and budget constraints while maximizing the number of credits reached under LEED rating system (Castro-Lacouture et al., 2009).

The previous researchers had investigated reduction of energy consumption for green buildings, development of water conservation systems and sustainable tools for quantifying success on sustainability and green buildings. There is a lack of research, however, on possible environmental, economic and social factors negatively contributing to the implementation of green buildings in the local construction industry. This paper thus aims: i) to examine the factors affecting the implementation of green buildings in the local construction industry; and ii) to recommend measures to improve green building implementation. 


\section{RESEARCH METHODOLOGY}

To achieve the objectives of this paper in examining the factors in terms of economic and social factors in implementing green buildings in the local construction industry, a questionnaire survey was conducted. Factors affected on economic and social issues were highlighted from the previous studies (Snook et al., 1995; Sjostrom and Bakens, 1999; Poon et al., 2004; Tam et al., 2004; Productivity Commission, 2006) and selected for the use in this paper in the questionnaire survey. The questionnaire (Pilot Questionnaire) was first sent to 10 practitioners. Face-to-face interviews were followed to receive comments and feedback to further improve the readability and suitability of the questionnaire. There are only minor amendments made in the wordings and better understanding of the questionnaire survey from the Pilot Questionnaire. The final questionnaire was sent to 300 parties including contractors, consultants, developers, governmental departments, and environmental professional associations who have experience in the implementation of green buildings. A total of 145 responses have been received with the response rate of about $48.3 \%$. However, three of the questionnaires were not properly completed and only 142 questionnaires are valid.

Data collected from the experimental work was analysed using the Statistical Package for Social Sciences (SPSS) Version 18.0 for Windows. Before the data was analysed and used for discussion, it is important to validate their reliability. Reliability analysis studies properties of measurement scales and individual items of the data. The reliability analysis procedure calculates a number of commonly-used measures of scale reliability and also provides information about the relationship among individual items in the scale. The data will not be useful if its reliability is low, which indicates that the data may wrongly be collected. One of the most popular reliability statistics is
Cronbach's alpha (Cronbach, 1951) which determines the internal consistency or average correlation of items in a survey instrument for gauging its reliability (Santos, 1999). The alpha parameter ranges from 0 to 1 , in which 0 means completely unreliable and 1 means perfectly reliable (Judd et al., 1991). A score of more than 0.5 is an acceptable reliable value. Cronbach's alpha can be computed using Equation (1) (Bland and Altman, 1997):

$$
\alpha=\frac{k \overline{\mathrm{cov} / \mathrm{var}}}{1+(k-1) \times \overline{\mathrm{cov} / \mathrm{var}}} \text { or } \frac{k \bar{r}}{1+(k-1) \bar{r}} \text { (if the }
$$

items are standardized to have the same variance)

where: $k$ is the number of items in the scale; $\overline{\mathrm{cov}}$ is the average covariance between items; $\overline{\mathrm{var}}$ is the average variance of the items; and $\bar{r}$ is the average correlation between items.

To determine the relative ranking of factors, scores were transformed to agreeance indices using Equation (2):

$$
R A I=\frac{\sum w}{A N}
$$

where: $w$ is the weighting given to each factor by the respondent, ranging from 1 to 5 in which ' 1 ' is strongly disagree and ' 5 ' strongly agree; $A$ is the highest significant of agreeance, in this study $A=5 ; N$ is the total number of samples; and $R A I$ is the relative agreeance in$\operatorname{dex}, 0 \leq R A I \leq 1$

After receiving the questionnaire responses, nine respondents from different business sectors agreed to participate in further individual interviews for reflective argumentation of the questionnaire results with two governmental officials, two building developers, one environmental consultant, three building contractors and one member of an environmental professional association. The interviews were intended to gather further comments; elaboration and interpretation on the results obtained from the questionnaire. 


\section{RESULTS AND ANALYSIS}

The reliability of the survey results is very high with the reliability in economic factor, social factor and overall of $0.934,0.865$ and 0.907 respectively. This forms a strong evidence to show that the data is highly reliable, which validates the below discussions.

\section{Economic factor}

Table 1 summarises the survey results on economic factor. "Using energy efficient systems can perform an increase in initial building cost" obtained the RAI value of about 0.74 from the survey results. An interviewed environmental consultant noted that energy efficient systems have a higher initial investment cost than the conventional system, thus construction cost will also be increased. However, the interviewee also stated that longterm cost for energy efficient systems is lower than that for the conventional systems, which include less maintenance cost and longer service life.

"Green materials are difficult to buy it locally and additional cost may be required for transportation" and "Materials used for constructing green building features cost more than those for constructing the conventional buildings" measured the RAI values of about 0.74 and 0.71 respectively from the survey results. An interviewed building contractor explained that green materials normally required more preparation processes and procedures for the production activities than the conventional materials. Treatments may also be required for the production processes. Another interviewed contractor noted that some green materials are not locally available which will significantly increase the material cost. Therefore, it is quite understandable that green materials cost more than the conventional materials, which builds up one of the major barriers for the industry in the implementation of green buildings.

"Installing green features will increase total construction cost" measured the RAI value of about 0.69 from the survey results. An interviewed building contractor noted that adopting green building features for residential buildings costs more than adopting commercial buildings.

Table 1. Summary of survey results on economic factors

\begin{tabular}{|c|c|c|c|c|c|c|}
\hline & \multicolumn{5}{|c|}{ Agreeance (in \%) } & \multirow[t]{2}{*}{ RAI } \\
\hline & $\begin{array}{l}1 \\
\text { Strongly } \\
\text { disagree }\end{array}$ & 2 & 3 & 4 & $\begin{array}{l}5 \\
\text { Strongly } \\
\text { agree }\end{array}$ & \\
\hline $\begin{array}{l}\text { Using energy efficient systems can perform } \\
\text { an increase in initial building cost }\end{array}$ & 0 & 0 & 47 & 38 & 15 & 0.74 \\
\hline $\begin{array}{l}\text { Green materials are difficult to buy it } \\
\text { locally and additional cost may be required } \\
\text { for transportation }\end{array}$ & 0 & 8 & 31 & 46 & 15 & 0.74 \\
\hline $\begin{array}{l}\text { Materials used for constructing green } \\
\text { building features cost more than that for } \\
\text { constructing the conventional buildings }\end{array}$ & 0 & 8 & 38 & 46 & 8 & 0.71 \\
\hline $\begin{array}{l}\text { Installing green features will increase total } \\
\text { construction cost }\end{array}$ & 0 & 23 & 23 & 39 & 15 & 0.69 \\
\hline Green design will increase design fee & 0 & 8 & 54 & 23 & 15 & 0.69 \\
\hline $\begin{array}{l}\text { Designing green buildings are more time } \\
\text { consuming than designing the conventional } \\
\text { buildings }\end{array}$ & 0 & 31 & 38 & 23 & 8 & 0.62 \\
\hline
\end{tabular}


One of the main reasons for this is that suppliers of green materials and energy-efficient systems for commercial buildings are readily available which increases cost due to the limited supply for residential buildings.

"Green design will increase design fee" and "Designing green buildings are more time consuming than designing the conventional buildings" obtained the RAI values of about 0.69 and 0.62 respectively from the survey results. These two statements surveyed designing issues in regarding to green building features. From the interview discussions, an interviewed designer noted that green building designs cost a bit higher than the conventional designs as the designers need research on the building environment, including directions, weather patterns and temperatures. By understanding the building environment, natural lighting and natural ventilation can be effectively facilitated for green buildings. Therefore, designing green buildings may have higher design fee and take longer time than designing the conventional buildings.

\section{Social factor}

From the survey results in Table 2, "Green buildings are more environment-friendly than the conventional buildings" obtained the RAI value of about 0.94. From the interview discussions, the interviewees all agreed that green buildings are undoubtedly environment-friendly. They noted that constructing green buildings is the trend around the world, which can extend life cycle, reduce waste generation and achieve sustainable performance. An interviewed contractor highlighted that the existing practice is an initial implementation or a trial period for green buildings. The government needs to input sufficient resources, standards and specifications to help implement green buildings in the local construction industry. An interviewed developer also stated that the government should first implement green building practices for all governmental projects.

'Awareness for green building by the society is better than before' obtained the RAI value of about 0.88 from the survey results, which includes about $38 \%$ and $62 \%$ of the respondents strongly agree and agree with the statement respectively. It is noted that respondents are more aware of green buildings in the society than ever before. An interviewed environmental consultant highlighted that green building development in the market is growing quite rapidly in recent years. Another interviewed contractor explained that this may due to the increasing number of residential projects incorporating green building features in their design and construction activities.

Table 2. Summary of survey results on social factors

\begin{tabular}{|c|c|c|c|c|c|c|}
\hline & \multicolumn{5}{|c|}{ Agreeance (in \%) } & \multirow[t]{2}{*}{ RAI } \\
\hline & $\begin{array}{l}1 \\
\text { Strongly } \\
\text { disagree }\end{array}$ & 2 & 3 & 4 & $\begin{array}{l}5 \\
\text { Strongly } \\
\text { agree }\end{array}$ & \\
\hline $\begin{array}{l}\text { Green building are more environment- } \\
\text { friendly than the conventional } \\
\text { buildings }\end{array}$ & 0 & 0 & 0 & 28 & 72 & 0.94 \\
\hline $\begin{array}{l}\text { Awareness for green building by the } \\
\text { society is better than before }\end{array}$ & 0 & 0 & 0 & 62 & 38 & 0.88 \\
\hline $\begin{array}{l}\text { Buildings with green building features } \\
\text { are more attractive to the consumers } \\
\text { than the conventional buildings }\end{array}$ & 0 & 0 & 54 & 31 & 15 & 0.72 \\
\hline
\end{tabular}


"Building with green building features are more attractive to the consumers than the conventional buildings" obtained the RAI value of about 0.72 from the survey results. The respondents agreed that buildings with green building features are more attractive than the conventional buildings. One of the interviewed developers highlighted that the attraction from green building features is evident and they believed that it could help improve building values. The interviewed consultants also agreed that local developers are eager to adopt innovative designs and green elements in the housing development.

\section{DISCUSSION}

This paper examines the major economical and social factors in green building implementation for the local construction industry. It is found that the social factors are not the major difficulties in the implementation; however it has been found that the economical factor is the major burden for the industry. Building cost, material cost, transportation cost and design cost are increased if a green building is implemented for the project, which is similar as the previous studies (Chan et al., 2009; Al-Salaymeh et al., 2010; Issa et al., 2010; Hang et al., 2011; Tam et al., 2011). It was also found that the initial cost is higher for a green building compared to the conventional building; however, a green building can be significantly saved on maintenance cost and improved life cycle costing.

From the interview discussions, the interviewees highlighted several factors affecting the existing limited implementation of green buildings in the local construction industry:

- Incomplete integration within and among projects: Incomplete integration means that project parties could not prepare green building concepts for buildings at the beginning of projects and cannot control different green building features in a whole. The main reasons for these barriers are lack of a clear green design goal, mid-steam attempts to incorporate green and decentralized management of the green building processes.

- Lack of experience, knowledge and standards on the implementation of green buildings: This causes designers, architects and clients to be conservative when using relatively new green technologies and systems. They may oversize green building systems and not fully integrating them into the building, thereby reducing cost savings and other benefits. For example, design teams may waste time researching inappropriate technologies, owners could accept a bid that prices too high for commissioning services. Cost estimators may add uncertainty factors for new green technologies that they are not familiar with, and these can compound, further inflating the cost estimates. The lack of commonly-accepted standards for green buildings further acts as a reason to fluctuate the minds of developers in green building concepts. There is lack of green building standards in the local construction industry. No one can show what a green building is, and no regulation can be followed. In addition, the lack of cost consumption for green buildings is another important factor.

- Lack of life cycle costing knowledge: The local construction industry is relatively more conservative than overseas markets for green buildings. This fact can be drawn when reviewing the acceptance of new technologies, such as top-down construction methods. Therefore, green building features require high initial investment and high return rates over a short period which complicates the design process. Alternatively, less innovative designs could be passed to the industry which may conservatively limit the cost efficiency. 
- Insufficient time and funding: If building teams did not have sufficient time and funding to search for new green products, components and technologies, green building designs cannot be implemented. Limited time and funding may therefore restrict the opportunities to create costefficient designs.

Based on the above discussions, the following measures are recommended to improve the implementation of green buildings in the local construction industry:

- The government needs to initiate the implementation of green buildings for all projects and to clearly highlight benefits and difficulties which may be encountered to the industry. This can significantly build up the industry confidence in green building implementation at the initial stage.

- A clear guideline or standard on the implementation of green buildings with detailed procedures is necessary to reduce possible uncertainties for designers, architects and clients in the implementation.

- Suppliers should provide a list of available resources, including recycled materials and green building features to the industry. Storage locations for the relevant materials and features are also required to build awareness in the industry of material availability, transportation cost and required time before designing green buildings. A central database system is recommended to collect all available resources.

- The government can mandatorily require the implementation of green buildings for all commercial buildings at the initial stage to initiate the importance of green buildings, as the materials and resources for commercial buildings are more well-developed than other building types. Other building types can gradually be implemented after the success of the commercial buildings. Incentives should also be provided for the initial implementation of green buildings.

The experience from this study can also be effectively implemented in other countries.

\section{CONCLUSION}

This paper examined economical and social factors affecting green building implementation for the local construction industry. Questionnaire survey and structured interviews were conducted. From the survey results, the industry believed that implementing green buildings can help improve the economic and social issues in the local construction industry. However, the industry highlighted that design, material, construction and transportation cost for green buildings are higher than those for the conventional buildings which creates the major burden for the implementation. Incomplete integration within and among projects, lack of experience, knowledge and standards on the implementation of green buildings, lack of life cycle costing knowledge, insufficient time and funding were the four major factors affecting the existing limited implementation of green buildings. Recommendations to improve the existing implementation of green building were also suggested.

\section{ACKNOWLEDGEMENTS}

The author would like to thank Mr. MingFai Li for conducting the survey.

\section{REFERENCES}

Al-Salaymeh, A., Al-Hamamre, Z., Sharaf, F. and Abdelkader, M. R. (2010) Technical and economical assessment of the utilization of photovoltaic systems in residential buildings: the case of Jordan, Energy Conversion and Management, 51(8), pp. 1719-1726.

http://dx.doi.org/10.1016/j.enconman.2009.11.026 
Ball, J. (2002) Can ISO 14000 and eco-labelling turn the construction industry green?, Building and Environment, 37(4), pp. 421-428. http://dx.doi.org/10.1016/S0360-1323(01)00031-2

Bland, J. M. and Altman, D. G. (1997) Statistics notes: Cronbach's alpha, British Medical Journal, 314, pp. 572 .

http://dx.doi.org/10.1136/bmj.314.7080.572

BRE (2011) Building research establishment environmental assessment method. [Online] Available at: http://www.bre.co.uk [accessed $23 \mathrm{Au}$ gust 2011]

Burnett, J. (2007) City buildings-Eco-labels and shades of green!, Landscape and Urban Planning, 83(1), pp. 29-38. http://dx.doi. org/10.1016/j.landurbplan.2007.09.003

California Integrated Waste Management Board (2011) Integrated waste management. [Online] Available at: http://www.ciwmb.ca.gov/GreenBuilding [accessed 23 August 2011]

Castro-Lacouture, D., Sefair, J. A., Florez, L. and Medaglia, A. L. (2009) Optimization model for the selection of materials using a LEEDbased green building rating system in Colombia, Building and Environment, 44(6), pp. 1162-1170. http://dx.doi.org/10.1016/j. buildenv.2008.08.009

CET (1999a) Environmental assessment method for existing office building, Centre of Environmental Technology Limited.

CET (1999b) Environmental assessment method for new office designs, Centre of Environmental Technology Limited.

CET (1999c) Environmental assessment method for new residential building, Centre of Environmental Technology Limited.

Chan, E. H. W., Qian, Q. and Lam, P. T. I. (2009) The market for green building in developed Asian cities-the perspectives of building designers, Energy Policy, 37(8), pp. 3061-3070. http://dx.doi.org/10.1016/j.enpol.2009.03.057

Chang, N. B., Rivera, B. J. and Wanielista, M. P. (2011) Optimal design for water conservation and energy savings using green roofs in a green building under mixed uncertainties, Journal of Cleaner Production, 19(11), pp. 1180-1188. http://dx.doi.org/10.1016/j.jclepro.2011.02.008

Chau, C. K., Tse, M. S. and Chung, K. Y. (2010) A choice experiment to estimate the effect of green experience on preferences and willingness-to- pay for green building attributes, Building and Environment, 45(11), pp. 2553-2561.

http://dx.doi.org/10.1016/j.buildenv.2010.05.017

Cheng, C. L. (2003) Evaluating water conservation measures for Green Building in Taiwan, Building and Environment, 38(2), pp. 369-379. http://dx.doi.org/10.1016/S0360-1323(02)00062-8

Cronbach, L. J. (1951) Coefficient alpha and the internal structure of tests, Psychometrika, 16(3), pp. 297-334.

http://dx.doi.org/10.1007/BF02310555

Ding, G. K. C. (2008) Sustainable construction-the role of environmental assessment tools, Journal of Environmental Management, 86(3), pp. 451-464.

http://dx.doi.org/10.1016/j.jenvman.2006.12.025

Green Building Council Australia (2011) Green building characteristics. [Online] Available at: http://www.gbcaus.org/ [accessed 23 August 2011]

Griffith, A. (1995) Environmental management systems: an outline guide for construction industry organizations, Department of Building and Real Estate, The Hong Kong Polytechnic University, Hong Kong.

Haapio, A. and Viitaniemi, P. (2008) A critical review of building environmental assessment tools, Environmental Impact Assessment Review, 28(7), pp. 469-482.

http://dx.doi.org/10.1016/j.eiar.2008.01.002

Hang, Y., Qu, M. and Zhao, F. (2011) Economical and environmental assessment of an optimized solar cooling system for a medium-sized benchmark office building in Los Angeles, California, Renewable Energy, 36(2), pp. 648-658. http://dx.doi.org/10.1016/j.renene.2010.08.005

Hong Kong Government - Environmental Protection Department (2011) Environmental protection. [Online] Available at: http://www.epd.gov. hk/epd/english/environmentinhk/waste/data/ waste_mon_swinhk.html [accessed 23 August 2011]

Indian Green Building Council (2011) Green building requirements. [Online] Available at: http:// www.igbc.in/igbc/read.jsp?reqpage [accessed 23 August 2011]

Issa, M. H., Rankin, J. H. and Christian, A. J. (2010) Canadian practitioners' perception of research work investigating the cost premiums, longterm costs and health and productivity benefits 
of green buildings, Building and Environment, 45(7), pp. 1698-1711.

http://dx.doi.org/10.1016/j.buildenv.2010.01.020

Judd, C. M., Smith, E. R. and Kidder, L. H. (1991) Research methods in social relations. Orlando: Ted Buchholz.

Kasai, Y. (2004) Recent trends in recycling of concrete waste and use of recycled aggregate concrete in Japan. In: ACI Syposium Publications: recycling concrete and other materials for sustainable development, 219, pp. 11-34.

Kates, G. (2011) Green building costs and financial benefits. [Online] Available at: http://www. cap-e.com/ [accessed 23 August 2011]

Louisiana-Pacific Corporation (2011) Green building definition. [Online] Available: http://www. lpcorp.com/radiantbarrier/productinformation/ glossary.aspx [accessed 23 August 2011]

Ma, Q., Wang, R. Z., Dai, Y. J. and Zhai, X. Q. (2006) Performance analysis on a hybrid airconditioning system of a green building, Energy and Buildings, 38(5), pp. 447-453. http://dx.doi.org/10.1016/j.enbuild.2005.08.004

Morledge, R. and Jackson, F. (2001) Reducing environmental pollution caused by construction plant, Environmental Management and Health, 12(2), pp. 191-206.

http://dx.doi.org/10.1108/09566160110389933

Pan, Y., Yin, R. and Huang, Z. (2008) Energy modeling of two office buildings with data center for green building design, Energy and Buildings, 40(7), pp. 1145-1152.

http://dx.doi.org/10.1016/j.enbuild.2007.10.008

Paul, W. L. and Taylor, P. A. (2008) A comparison of occupant comfort and satisfaction between a green building and a conventional building, Building and Environment, 43(11), pp. 18581870.

http://dx.doi.org/10.1016/j.buildenv.2007.11.006

Polster, B., Peuportier, B., Sommereux, I., Pedregal, P., Gobin, C. and Durand, E. (1996) Evaluation of the environmental quality of buildings towards a more environmentally conscious design, Solar Energy, 57(3), pp. 219-230.

http://dx.doi.org/10.1016/S0038-092X(96)00071-0

Poon, C. S., Yu, A. T. W., See, S. C. and Cheung, E. (2004) Minimizing demolition wastes in Hong Kong public housing projects, Construction Management and Economics, 22(8), pp. 799-805.

http://dx.doi.org/10.1080/0144619042000213283
Productivity Commission (2006) Waste management: productivity commission draft report, Productivity Commission, Australian Government.

Santos, J. R. A. (1999) Cronbach's alpha: a tool for assessing the relliability of scales, Journal of Extension, 37(2), pp. 1-5.

Sjostrom, C. and Bakens, W. (1999) CIB Agenda 21 for sustainable construction: why, how and what, Building Research and Information, 27(6), pp. 347-353.

http://dx.doi.org/10.1080/096132199369174

Snook, K., Turner, A. and Ridout, R. (1995) Recycling waste from the construction site. England: Chartered Institute of Building.

Tam, C. M., Tam, V. W. Y. and Tsui, W. S. (2004) Green construction assessment for environmental management in the construction industry of Hong Kong, International Journal of Project Management, 22(7), pp. 563-571.

http://dx.doi.org/10.1016/j.ijproman.2004.03.001

Tam, W. Y. V., Zhang, X., Lee, W. W. Y. and Shen, L. Y. (2011) Applications of extensive green-roof systems in contributing to sustainable development in densely populated cities: a Hong Kong study, Australasian Journal of Construction Economics and Building, 11(1), pp. 15-25.

Tatari, O. and Kucukvar, M. (2011) Cost premium prediction of certified green buildings: a neural network approach, Building and Environment, 46(5), pp. 1081-1086.

http://dx.doi.org/10.1016/j.buildenv.2010.11.009

The Seattle City Light Web Team (2011) Northwest regional sustainable building action plan. [Online] Available: http://www.seattle.gov/light/ conserve/sustainability/cv5_fpln.htm [accessed 23 August 2011]

USGBC (2011) Leadership in energy and environmental design. [Online] Available at: http:// www.usgbc.org/ [accessed 23 August 2011]

Wang, W., Zmeureanu, R. and Rivard, H. (2005) Applying multi-objective genetic algorithms in green building design optimization, Building and Environment, 40(11), pp. 1512-1525. http://dx.doi.org/10.1016/j.buildenv.2004.11.017

Wedding, G. C. and Crawford-Brown, D. (2007) Measuring site-level success in brownfield redevelopments: a focus on sustainability and green building, Journal of Environmental Management, 85(2), pp. 483-495.

http://dx.doi.org/10.1016/j.jenvman.2006.10.018 
Yang, K. H. and Hwang, R. L. (2007) An improved assessment model of variable frequency-driven direct expansion air-conditioning system in commercial buildings for Taiwan green building rating system, Building and Environment, 42(10), pp. 3582-3588.

http://dx.doi.org/10.1016/j.buildenv.2006.10.015

Zhai, X. Q. and Wang, R. Z. (2009) Experimental investigation and theoretical analysis of the solar adsorption cooling system in a green building, Applied Thermal Engineering, 29(1), pp. 17-27. http://dx.doi.org/10.1016/j. applthermaleng.2008.01.028

Zhai, X. Q., Wang, R. Z., Dai, Y. J., Wu, J. Y., Xu, Y. X. and $\mathrm{Ma}, \mathrm{Q}$. (2007) Solar integrated energy system for a green building, Energy and Buildings, 39(8), pp. 985-993.

http://dx.doi.org/10.1016/j.enbuild.2006.11.010 